\title{
Definiowanie wybranych derywatów słowotwórczych i wyrazów wieloznacznych przez osobę niepełnosprawną intelektualnie w stopniu lekkim (studium przypadku)
}

Krzysztof Hryckowian | Wydział Filologiczny, Uniwersytet Gdański

Słowa kluczowe:

derywat, kompetencja semantyczna sprawność leksykalna niepełnosprawność intelektualna

\section{Streszczenie}

Przedmiotem artykułu jest opis kompetencji słowotwórczej i semantycznej dwudziestosiedmioletniej Sary niepełnosprawnej intelektualnie w stopniu lekkim z niedosłuchem obustronnym. Celem jest potwierdzenie tezy o tym, że deficyty intelektualne mogą utrudniać wskazywanie relacji formalno-semantycznej oraz odczytywanie wyrazów wieloznacznych. Przeprowadzona analiza jest próbą określenia sprawności w zakresie sposobów określania i rozpoznawania cech wybranych konstrukcji słowotwórczych i wyrazów wieloznacznych, oraz ukazania specyficznych cech treści znaczeniowej pojęcia, co może być wskazówką do opracowania właściwego postępowania logopedycznego.

An analysis of selected word formation processes and ambiguous words produced by an intellectually disabled person (case study)

Abstract

Keywords:

derivation,

semantic competence, lexical efficiency, intellectual disability

The aim of this paper is to describe the word formation and semantic competence of Sarah, a 27-year-old woman suffering from a mild form of intellectual disability in order to confirm the claim that intellectual deficits can impede recognize of formal-semantic relations and interpretation of ambiguous words. The analysis is aimed at demonstrating the specific characteristics of denotative semantics which may prove to be a guideline for the application of appropriate speech therapy. 


\section{Wstęp}

Trudno wyobrazić sobie życie bez języka, który pozwala porozumiewać się z drugim człowiekiem, wyrażać swoje myśli, emocje, interpretować świat i zaspokajać potrzeby. Na pytanie, w jaki sposób można funkcjonować bez komunikacji, nie ma jednoznacznej odpowiedzi. W wypadku deficytów językowych dziecko zostaje pozbawione możliwości posługiwania się określonym kodem komunikacyjnym i kulturowym, ponieważ „opanowanie języka otwiera przed dzieckiem możliwości poznania świata. Niemożność przyswojenia języka skazuje dziecko na namiastkową, w dużej części biologiczną, orientację w rzeczywistości i pozostawia je w jego własnym wyizolowanym świecie" (Panasiuk 2015: 36). Wówczas staje się niezrozumiałe dla otoczenia, dziwne, wyraża swoje myśli tak, jak potrafi, oraz bywa depresyjne w przypadku utraty mowy. Dziecko z niedorozwojem może być nieśmiałe, apatyczne i wycofane, ale to nie zawsze jest regułą. Kiedy bliska nam osoba przestaje posługiwać się mową, zaczynamy zdawać sobie sprawę z wagi i wartości, jaką daje komunikacja werbalna.

U osób z niepełnosprawnością intelektualną trudności z rozumieniem i mówieniem są zauważalne od samego początku kształtowania się mowy. Osoby takie nie są dostatecznie rozumiane przez otoczenie i same też w pewnych sytuacjach komunikacyjnych nieadekwatnie używają znaczeń słów. Utrudnia to ich funkcjonowanie w środowisku, naukę szkolną itp. Prezentowany wyżej obraz osób niepełnosprawnych intelektualnie jest z konieczności bardzo uogólniony. Dlatego warto bliżej przyjrzeć się problemom komunikacyjnym osób z deficytami intelektualnymi.

W niniejszym artykule postaram się omówić sposoby konstruowania parafrazy słowotwórczej, rozpoznawania derywatów na podstawie definicji słowotwórczej oraz rozpoznawania i precyzowania znaczeń wyrazów wieloznacznych przez dwudziestosiedmioletnią Sarę, która od urodzenia jest niepełnosprawna intelektualnie w stopniu lekkim. Celem moich rozważań jest poszukiwanie odpowiedzi na następujące pytania: czy Sara lepiej radzi sobie z tworzeniem derywatów niż z ich rozumieniem? jaki typ wiedzy o świecie ujawnia się w definiowanych przez badaną wyrazach? czy niepełnosprawność intelektualna w stopniu lekkim wpływa na kompetencję słowotwórczą i semantyczną?

Pacjentka została przeze mnie przebadana za pomocą specjalnie zaprojektowanego kwestionariusza, w którym musiała podać parafrazę słowotwórczą wybranych derywatów, przywołać z własnego zasobu leksykalnego na podstawie parafrazy słowotwórczej i cech semantycznych konkretne derywaty oraz zdefiniować niektóre wyrazy wieloznaczne. Czas badania dostosowany został do możliwości psychofizycznych badanej. Ze względu na to, że kwestionariusz jest długi, badanie podzielono na trzy części oraz robiono przerwy, aby zachęcić pacjentkę do udziału w badaniu. Metodą, którą wykorzystałem do interpretacji wyników, jest studium przypadku'. Sięgnąłem

${ }^{1}$ Studium przypadku (case study) jest metodą powszechnie stosowaną w naukach ekonomicznych (ekonomii, finansach), prawnych, społecznych (dziennikarstwie, psychologii, logopedii), humanistycznych (lingwistyce), 
do tej techniki, ponieważ daje ona możliwość analizowania oddziaływania określonego czynnika na mowę oraz wpływu zaburzeń mowy na całościowe funkcjonowanie osoby (Banaszkiewicz 2015: 374).

Przedstawiona przeze mnie analiza jest jedynie wstępem do dalszych rozważań, powstała na potrzeby otwartego seminarium doktoranckiego prowadzonego w ramach Filologicznych Studiów Doktoranckich na Wydziale Filologicznym Uniwersytetu Gdańskiego.

Pragnę serdecznie podziękować pani prof. nadzw. dr hab. Katarzynie Wojan, prowadzącej seminarium otwarte, za motywację do rzetelnego przygotowania studium, cenne wsparcie i okazaną życzliwość, pani dr Katarzynie Kaczorowskiej-Bray z Katedry Logopedii Uniwersytetu Gdańskiego za wnikliwą lekturę artykułu, znaczące uwagi i fachowe rady, oraz pani prof. nadzw. dr hab. Alinie Maciejewskiej z Uniwersytetu Przyrodniczo-Humanistycznego w Siedlcach za okazaną cierpliwość i wskazówki metodologiczne, dzięki którym moja praca zyskała inną wartość poznawczą.

\section{Definiowanie}

Definiowanie wyrazów to umiejętność kategoryzacji, konceptualizacji znaczenia danej jednostki leksykalnej, werbalizowania znaczenia, odnosząca się do sfery świadomości i kompetencji lingwistycznej (Binkuńska 2012: 164). W rozumieniu kognitywnym znaczenie wyrażenia można podać, posługując się złożonymi słowami. Wówczas nie jest to analiza składników znaczenia, tylko opis właściwości charakterystycznych dla sytuacji lub przedmiotu w rzeczywistości pozajęzykowej i utrwalonym w obrazie doświadczonym w strukturze umysłu (Nowakowska-Kempna 1993: 168). Lingwistyka kognitywna wyróżnia prototyp rozumiany jako proces prototypizacji, czyli definiowania i produktu prototypizacji zwanego definicją (Nowakowska-Kempna 1993: 170). Prototyp wiąże się ściśle z takimi procesami jak ustalanie rodzinnego podobieństwa, wybór najlepszego członka kategorii, mającego najwięcej rodzinnych cech wspólnych, kategoryzacja, abstrahowanie i uogólnienie (Nowakowska-Kempna 1993: 170). Kategoryzacja - jak pisze Ewa Binkuńska - to proces poznawczy zachodzący w obszarze mentalnym na podstawie posiadanej wiedzy i pozwalający określić zakres pojęć, którymi posługują się ludzie, oraz sposób ich porządkowania, cechą kategoryzacji jest zasada dopasowania (Binkuńska 2012: 164). Według Binkuńskiej werbalizacja polega na wyrażaniu znaczenia danego pojęcia za pomocą słów i dokonywana jest na podstawie kategoryzacji. Z kolei konceptualizację badaczka wiąże z wyodrębnieniem i określeniem właściwym danemu pojęciu cech semantycznych (Binkuńska 2012: 164). W świetle teorii kognitywnej kategoryzacja świata nie ma charakteru obiektywnego, lecz jest pewną interpretacją rzeczywistości, którą

interdyscyplinarnych (zarządzaniu), medycznych (medycynie) i naukach o zdrowiu (zdrowiu publicznym), o turystyce. Pozwala odwołać się do zachowań językowych izapoznać się z sytuacją konkretnej osoby (Banaszkiewicz 2015: 364-373). 
narzuca umysł poznający ustalający subiektywnie podobieństwa między obiektami (za: Grzegorczykowa, Szymanek 2001: 463). Podstawowe pojęcia są przez człowieka wyrażane za pomocą kategorii gramatycznych, które opisują elementy świata regularnie i obowiązkowo, a także w sposób nieregularny i nieobligatoryjny za pomocą kategorii słowotwórczych (kategorii pojęciowych) poprzez wykorzystanie określonych wykładników (Grzegorczykowa, Szymanek 2001: 463). Aspekt poznawczy zjawisk słowotwórczych ujawnia się na poziomie klas leksemów i na poziomie nazw poszczególnych obiektów, obiekt może być nazwany przez wskazanie na różne jego cechy (Grzegorczykowa, Szymanek 2001: 463).

Niezbędnym elementem służącym opisywaniu znaczenia jest definicja. Na potrzeby niniejszej pracy odwołuję się do pojęcia definicji kognitywnej. Głównym celem definicji kognitywnej ${ }^{2}$ jest zdanie sobie sprawy ze sposobu pojmowania przedmiotu przez mówiących danym językiem, tj. sposobu utrwalonej społecznie i dającej się poznać poprzez język i użycie języka wiedzy o świecie, kategoryzacji jego zjawisk, ich charakterystyki i wartościowania (Bartmiński 2007: 44). Treść, która jest przywoływana w definicji, powinna mieć charakter poznawczy, a nie czysto semantyczny. Przedmiotem opisu w definicji kognitywnej jest zwykle "przedmiot mentalny”, który jest projekcją danego przedmiotu, a nie jego odbiciem. Nie ma znaczenia, że przedmiot może być porównywany z przedmiotem rzeczywistym, dostępnym doświadczeniu empirycznemu (Bartmiński 2007: 44). W ujęciu kognitywnym interpretacja znaczenia powinna być adekwatna do kompetencji językowej użytkowników danego języka, bo wówczas istnieje możliwość pokazania głębokiego, wewnętrznego związku języka z kulturą społeczności. Definicja kognitywna ukazuje, że znaczenie słowa jest determinowane kulturowo oraz jest nastawione na treści poznawcze utrwalone w języku, a także odkrywa sposoby strukturyzowania treści poprzez język. Jednocześnie nie dopuszcza się selektywności ograniczającej liczbę cech koniecznych i wystarczających do identyfikacji denotatu. Warto zatem podjąć próbę wykorzystania koncepcji Jerzego Bartmińskiego w procesie definiowania pojęć przez osoby niepełnosprawne intelektualnie w stopniu lekkim, ponieważ pozwoli to inaczej spojrzeć na wiedzę tych osób o otaczającym ich świecie oraz sprawdzić, czy ich sposób poznawania świata rzeczywiście odbiega od normy. Trudno też ocenić, czy niepełne opanowanie systemu językowego wpływa znacząco na opisywanie przedmiotów oraz uczestnictwo w życiu kulturalnym i społecznym.

Formułując definicję kognitywną konkretnego leksemu, uwzględnić należy znaczenia konotacyjne. Znaczenia wyrazów są ustabilizowanymi w danej społeczności związkami między ciągami dźwięków a wyróżnionymi przez mówiących klasami zjawisk rzeczywistych (Grzegorczykowa 2010: 60). Kiedy opisujemy znaczenie wyrazu, przedstawiamy kompetencję semantyczną użytkowników posługujących się danym językiem. Zdaniem Renaty Grzegorczykowej (2010) należy wówczas uwzględnić, że wiele znaczeń wyrazów charakteryzuje się pewną nieokreślonością, która znajduje

${ }^{2}$ Określenie kognitywny pochodzi od łac. cognosco 'poznaję'. 
przejaw w różnym rozumieniu i innym sposobie identyfikacji zjawisk przez użytkowników języka. Wiedza o języku nie jest wiedzą o świecie; ta wiedza pozwala jedynie na zbadanie świadomości odniesienia wyrazów do zjawisk. Elementy konotacyjne (asocjacyjne) informują o pewnych cechach nieistotnych, kojarzonych przez mówiącego ze zjawiskami nazywanymi. Wskazanie pewnego obiektu w świecie nie jest jeszcze wystarczające, ponieważ należy wydobyć wszystkie informacje przez dane wyrażenie przekazywane.

Interpretacja definiowanych znaczeń przez osoby z niepełnosprawnością intelektualną nie jest czynnością łatwą, bowiem wymaga rozbudowanego aparatu badawczego. Dlatego wydaje mi się słuszne uwzględnienie koncepcji Ewy Binkuńskiej, Jerzego Bartmińskiego i Renaty Grzegorczykowej dotyczące definiowania. Zasób wiedzy osób niepełnosprawnych intelektualnie bywa różny, tak samo zresztą jak ich kompetencja językowa, co niewątpliwie wpływa na umiejętność kategoryzowania pozwalającą klasyfikować obiekty ${ }^{3}$. Uczniowie z deficytami intelektualnymi pochodzą z różnych środowisk. Mogą być mobilizowani do nieustannego poszerzania wiedzy i wówczas wykazują się niezwykłą determinacją w pracy albo też bywają negatywnie nastawiani do nauki w szkole. Często tak zdarza się w wypadku uczniów z rodzin patologicznych.

\section{Derywat słowotwórczy}

Słowotwórstwo jest podstawowym sposobem wzbogacania systemu leksykalnego. Pozwala na tworzenie wyrazów i pomaga użytkownikom nazywać oraz interpretować nowe pojęcia. Integralną i znaczącą częścią systemu słowotwórczego jest derywat, zwany też konstrukcją słowotwórczą, formacja, wyrazem słowotwórczo podzielnym, wyrazem pochodnym słowotwórczo, motywowanym, fundowanym. Derywat definiowany jest jako konstrukcja zbudowana dwuczłonowo, pozostająca w relacji formalnej i semantycznej do swoich podstaw (Grzegorczykowa 1972: 19). Składa się on z tematu słowotwórczego i formantu słowotwórczego. Temat to baza, słowoforma, jednostka słownikowa, równa tematowi fleksyjnemu, zaś formant - element różniący derywat od podstawy, który utworzył derywat, znak formalny przekształcenia wyrazu podstawowego w derywat (Grzegorczykowa 1972: 29). Należy przyjąć, że formant uściśla, uwypukla znaczenie wyrazu, co daje możliwość przyporządkowywania wyrazów do określonych kategorii słowotwórczych, czyli klas wyrazów mających tę samą wartość kategorialną, na przykład kategoria wykonawców czynności to klasa o wartości 'ktoś wykonuje jakąś czynność' (Grzegorczykowa 1972: 44). W polskim słowotwórstwie wyróżnia się a. derywaty transpozycyjne, które nie zmieniają znaczenia, a jedynie funkcję składniową, b. derywaty mutacyjne, będące nazwami nowych

\footnotetext{
${ }^{3}$ Kompetencja językowa to „nieuświadamiana wiedza na temat gramatycznych zasad budowania zdań" (Grabias 2012: 58). Odzwierciedla stan pisanej i mówionej realizacji konstrukcji składniowych. Badający ma również możliwość oceny kompetencji poznawczej, związanej ze stanem wiedzy o świecie i o sobie, operowania segmentami wiedzy (Grabias 2012: 58).
} 
desygnatów, wyraz ma wówczas zmienioną funkcję semantyczną, oraz c. derywaty modyfikacyjne, wnoszące tylko pewną modyfikację znaczenia i komunikujące jakąś cechę desygnatu.

W polskiej literaturze lingwistycznej nie poświęcono dotychczas zbyt wiele uwagi kompetencji słowotwórczej dzieci, a badania sprawności słowotwórczej dzieci z niepełnoprawnością intelektualną nigdy nie były szczególnie eksplorowanym przedmiotem badań. Pewne obserwacje dotyczące przyswajania reguł słowotwórczych przeprowadziła jedynie Ewa Muzyka-Furtak (2015). Badaczka przebadała dzieci niesłyszące i słabosłyszące. Wyniki dokonanych analiz pokazały, że trudności z interpretacją konstrukcji słowotwórczych wpływają bezpośrednio na charakterystykę słownictwa dzieci niesłyszących i słabosłyszących (Muzyka-Furtak 2015: 179). Dzieci z uszkodzonym słuchem nie dostrzegają relacji formalno-semantycznych zachodzących między wyrazami lub dostrzegają je "po swojemu” (Muzyka-Furtak 2015: 179). Łatwiej jest im rozpoznać znaczenia konstrukcji modyfikacyjnych, szczególnie zdrobnień aniżeli mutacyjnych.

\section{Wieloznaczność}

Wieloznaczność wyrazu związana jest z tym, że między poszczególnymi znaczeniami winny zachodzić pewne związki, to znaczy, że musi istnieć między nimi jakiś wspólny nietrywialny element znaczenia (Grzegorczykowa 2010: 55). Istotą wieloznaczności jest podobieństwo przedmiotów, czyli rzeczywiste cechy wspólne.

Wyrazy wieloznaczne motywują się na ogół niepowtarzalnymi podobieństwami. Te ostatnie mogą zaś dotyczyć różnych cech, takich jak kształt, kolor (głowa człowieka - głowa kapusty, szafir, szmaragd 'kamień' i 'kolor'), podobieństwo funkcji, podobieństwa psychiczne (osioł 'zwierzę' i 'głupi człowiek'). W ujęciu kognitywnym wieloznaczność nie jest wyłącznie operacją czysto językową stosowaną w poezji, ale stanowi element służący percypowaniu świata (Grzegorczykowa 2010: 57).

\section{Językowe funkcjonowanie osób z niepełnosprawnością intelektualną}

Osoby z niepełnosprawnością intelektualną, których komunikacja językowa przebiega z różnego rodzaju trudnościami, stanowią około 1-3\% populacji (Kaczorowska-Bray 2017: 246). W literaturze logopedycznej, psychologicznej i pedagogicznej najczęściej podaje się czterostopniową klasyfikację niepełnosprawności intelektualnej ustaloną przez Komitet Amerykańskiego Towarzystwa Psychiatrycznego (American Psychiatric Association). Wyróżnia się zatem niepełnosprawność intelektualną: a. lekką, w zakresie ilorazu inteligencji 50-55 do około 70 punktów, b. umiarkowaną, 35-40 do 50-55 punktów, c. znaczną, 20-25 do 35-40 punktów, d. głęboką, poniżej 20-25 punktów (za Kowalik 2005: 147). Sprawność definiowania przy każdym stopniu niepełnosprawności wygląda nieco inaczej: przy lekkiej niepełnosprawności 
dziecko dobrze radzi sobie z definiowaniem pojęć konkretnych, ale nie podaje definicji przedmiotów abstrakcyjnych. Przy umiarkowanej - definiowanie pojęć opiera się głównie na opisie przedmiotu i materiału, z którego ten został zrobiony, albo przez ten zastosowany. Przy znacznej - dziecko definiuje pojęcia tylko przez zastosowanie, użycie przedmiotu, a przy głębokiej występuje jedynie reakcja na bodźce w ograniczonym zakresie (Błeszyński 2012: 189). Szczególne problemy z nabywaniem sytemu semantycznego mają dzieci z zespołem Downa, ponieważ trudności artykulacyjne uniemożliwiają im rozumienie znaczeń na podstawie danych językowych (Marszałek 2010: 181). Najpierw zatem posługują się odpowiednikami w postaci ikonicznej, co daje im możliwość identyfikacji z rzeczywistymi przedmiotami (Marszałek 2010: 181).

U dzieci z niepełnosprawnością intelektualną w stopniu lekkim rozwój mowy przebiega zazwyczaj tak jak w wypadku dzieci o typowym rozwoju (Kaczorowska-Bray 2012: 54), ale przytoczone przez Katarzynę Kaczorowską-Bray (2012: 54) badania Kuźniecowej wykazują, że u niektórych dzieci z niepełnosprawnością intelektualną w stopniu lekkim gaworzenie rozpoczyna się między pierwszym a drugim rokiem życia $(12,5 \%)$, do trzeciego roku życia $(3,2 \%)$, świadome wypowiadanie sylab i ich ciągów pojawia się między trzecim a czwartym rokiem życia $(14,4 \%)$, natomiast u 20,2\% pojedyncze wyrazy pojawiały się najwcześniej w drugim roku życia (za: Kaczorowska-Bray 2012: 54-55). Interesujący wydaje się fakt, że $25 \%$ badanych z omawianej grupy w etap wyrazu weszło między czwartym a piątym rokiem życia, natomiast fraza została zanotowana do szóstego roku życia u 22\% dzieci (Kaczorowska-Bray 2012: 55). Mimo opóźnienia rozwoju mowy dzieci te $w$ wieku przedszkolnym próbują nawiązywać kontakty społeczne. Opanowują system fonologiczny, semantyczny i syntaktyczny wolniej i z trudem, $w$ bardzo ograniczonym zakresie. $W$ momencie rozpoczęcia nauki szkolnej problemy językowe stają się dla nich bardzo uciążliwe. Zwykle wypowiedzi zbudowane są z równoważników, zdań prostych i jednokrotnie złożonych współrzędnie (Kaczorowska-Bray 2012: 55). Dzieci z niepełnosprawnością intelektualną w stopniu umiarkowanym pierwsze wyrazy wypowiadają około piątego roku życia, zdania - około siódmego roku życia. U dzieci ze znacznym upośledzeniem wyrazy pojawiają się dopiero w wieku szkolnym, natomiast u dzieci z głęboką niepełnosprawnością rozwój mowy zwykle zatrzymuje się na etapie melodii, niekiedy opanowują dwatrzy wyrazy (Kaczorowska-Bray 2012: 60).

Niełatwo stwierdzić, w jakim stopniu osoby upośledzone umysłowo będą w stanie dostatecznie opanować język, ponieważ im większe upośledzenie, tym później pojawiają się pierwsze słowa (Tarkowski 2005: 559). Zbigniew Tarkowski (2005: 569-570) wymienia następujące zaburzenia mowy u osób z deficytami intelektualnymi:

1. opóźniony rozwój mowy + dyslalia,

2. opóźniony rozwój mowy + jąkanie albo mowa bezładna,

3. opóźniony rozwój mowy + dyslalia + jąkanie,

4. opóźniony rozwój mowy + dysartria, 
5. opóźniony rozwój mowy + zaburzenia głosu + dyslalia,

6. opóźniony rozwój mowy + niedosłuch + dyslalia.

Zaburzenia mowy w wypadku upośledzenia umysłowego mogą być wielorakie, sprzężone i mogą znacznie częściej występować. Są ponadto trudne w korygowaniu. Badacze nie są przekonani, że iloraz inteligencji niższy od przeciętnego jest przyczyną opóźnionego rozwoju mowy (Kaczorowska-Bray 2017: 257). Trudno ocenić taki wskaźnik, bowiem im bardziej szczegółowo analizuje się strukturę języka osób niepełnosprawnych intelektualnie, tym orzekanie staje się bardziej skomplikowane (Kaczorowska-Bray 2017: 256). Mirosław Michalik w swych rozważaniach na temat pracy nad oceną i budowaniem kompetencji leksykalno-gramatycznej dzieci upośledzonych umysłowo odniósł się do trójkąta semantycznego Ogdgena i Richardsa. Wynika z niego, że kultura i język są wytworami intelektu, a praca nad usprawnianiem kompetencji lingwistycznej dzieci z niepełnosprawnością intelektualną powoduje u nich automatyczny wzrost sprawności intelektualnych i pełniejszą eksplorację rzeczywistości (zob. Michalik 2010: 48). Powyższe podejście najpełniej zarysowuje istotę zaburzeń mowy i języka u osób upośledzonych umysłowo, ponieważ wynika z niego, że zaburzenia komunikacji językowej wpływają na zubożenie wyrażania, nazywania pojęć.

Pacjenci niepełnosprawni intelektualnie ze względu na ograniczenia w sposobach komunikowania się często doświadczają różnego typu komunikacji (za: Tarkowski, Góral-Półrola 2012: 263-264)"

a. komunikacji interpersonalnej - czyli głębokiej ingerencji w Ja uczestników i całkowitego zniesienia ich prywatności, definiowania tożsamości uczestników z góry, bez ich udziału;

b. komunikacji bezosobowej, w której jednostka upośledzona pojmowana jest jako "To", w procesie porozumiewania używa się w tym wypadku form bezosobowych, na przykład: „niech wstanie, zje”;

c. komunikacji infantylnej, gdzie osobie upośledzonej umysłowo narzuca się rolę dziecka;

d. komunikacji zdystansowanej - wobec osób upośledzonych często zachowuje się dystans w celu unikania zbliżania do siebie, także odchodzi się od rozmów „twarzą w twarz";

e. komunikacji instrumentalnej, polegającej głównie na wydawaniu dyrektyw w formie rozkazów, próśb i zobowiązań.

Lekceważący i dyskryminujący sposób komunikowania wpływa negatywnie na rozwijanie mowy osoby niepełnosprawnej intelektualnie i całkowicie wyklucza ją z aktów komunikacji.

\footnotetext{
${ }^{4}$ Problem wymaga szerszego omówienia (zob. Michalik 2013: 107-138) i (Panasiuk 2013: 81-106). Temat niniejszego artykułu dotyczy jednak procesu definiowania, a nie interakcji, co nie pozwala na szczegółowe omówienie tego zagadnienia.
} 


\section{Metoda badania}

Na potrzeby analizy kompetencji leksykalnej i semantycznej Sary korzystałem ze standardów logopedycznych opracowanych przez zespół współpracowników Stanisława Grabiasa. W związku z tym przyjmuję za Grabiasem, że sprawność leksykalna jest związana z kulturową segmentacją świata, a słowa odsyłają do desygnatów i wyznaczają relację między nimi (Grabias et al. 2015: 20). Konstrukcje słowotwórcze odznaczają się szczególną dyskretnością w budowaniu relacji umysłowych. Sprawność semantyczną cechuje to, że zdrowy mózg porządkuje doświadczenia według uspołecznionego schematu, mózg chory odbiega dalece od takiego schematu (Grabias 2015: 20).

Pacjentka została przebadana za pomocą opracowanego kwestionariusza, podzielonego na trzy części. Przed przystąpieniem do badania przećwiczono z badaną wszystkie techniki (osobno do każdej kategorii słowotwórczej) celem uruchomienia umiejętności w zakresie słowotwórstwa. Derywaty w ramach kategorii transpozycji, mutacji i modyfikacji uporządkowałem według zestawu kategorii słowotwórczych zaproponowanych przez Renatę Grzegorczykową (1972). Z zakresu derywacji transpozycyjnej jako przedmiot analizy wybrałem: a. nazwy czynności, b. nazwy abstrakcyjnych cech. Z mutacyjnej wybrałem: a. nazwy wykonawców czynności; b. nazwy narzędzi; c. nazwy nosicieli cech; d. nazwy miejsc. Z derywatów modyfikacyjnych wybrałem: a. nazwy żeńskie; b. nazwy deminutywne (zdrobnienia). Wszystkie konstrukcje słowotwórcze umieszczone w kwestionariuszu pochodzą ze Szkolnego słownika języka polskiego PWN pod redakcją Lidii Drabik i Elżbiety Sobol, a wyrazy wieloznaczne - z Wielkiego słownika języka polskiego (2017) dostępnego w wersji online. Powodem sięgnięcia do tych źródeł jest założenie, że osoba dorosła z niepełnosprawnością intelektualną w stopniu lekkim dysponuje słownictwem na poziomie ucznia szkoły gimnazjalnej, natomiast wyboru wyrazów wieloznacznych dokonałem na podstawie kryterium dystrybucyjnego, są one powszechnie używane w języku potocznym. Analiza obejmuje derywaty rzeczownikowe sufiksalne, ponieważ sufiksacja jest najproduktywniejszym procesem słowotwórczym w języku polskim, a także charakteryzuje się wysoką częstotliwością występowania w języku dzieci i w języku ogólnym. Do analizy włączono tylko rzeczowniki, dlatego że są najliczniejszą klasą części mowy i są kategorią wyrazów najbardziej zróżnicowaną pod względem semantycznym i formalnym (za: Muzyka-Furtak 2010: 84).

W dwóch pierwszych częściach kwestionariusza zbadałem umiejętności: rozumienia (dekodowania) i tworzenia (kodowania) konstrukcji słowotwórczych. Metoda ta została opracowana przez Ewę Muzykę-Furtak, która za pomocą tego narzędzia przebadała dzieci niesłyszące (Muzyka-Furtak 2010: 91). Aby przebadać Sarę, postanowiłem wzorować się na tej metodzie. Każda ze sprawności była badana na dwa sposoby za pomocą dwóch technik (zob. tab. 1). 
Tab. 1. Zadania i techniki

\begin{tabular}{|l|l|l|}
\hline $\begin{array}{l}\text { ZADANIE 1 } \\
\text { Rozumienie konstrukcji }\end{array}$ & Technika 1 & Sformułowanie parafrazy słowotwórczej \\
\cline { 2 - 3 } & Technika 2 & $\begin{array}{l}\text { Dokonanie eksplikacji cech semantycznych składających się na } \\
\text { Znaczenie strukturalne konstrukcji }\end{array}$ \\
\hline $\begin{array}{l}\text { ZADANIE 2 } \\
\text { Tworzenie konstrukcji }\end{array}$ & Technika 1 & Na podstawie parafrazy słowotwórczej \\
\cline { 2 - 3 } & Technika 2 & $\begin{array}{l}\text { Na podstawie cech semantycznych składających się na znaczenie } \\
\text { strukturalne konstrukcji }\end{array}$ \\
\hline
\end{tabular}

Źródło: Muzyka-Furtak 2010: 91

Z a da n i e 1 - analizie podlegała umiejętność dekodowania (rozumienia) derywatów należących do poszczególnych kategorii słowotwórczych:

Technika 1 - umiejętność dekodowania konstrukcji słowotwórczych w postaci parafrazy słowotwórczej, na przykład:

a. Derywaty transpozycyjne:

Kto (co) to jest dokonanie?

Kto (co) to jest głupstwo?

Kto (co) to jest efektywność?

b. Derywaty mutacyjne

Kto (co) to jest marzyciel?

Kto (co) to jest rozbójnik?

Kto (co) to jest palmiarnia?

Kto (co) to jest sernik?

c. Derywaty modyfikacyjne

Kto (co) to jest kocica?

Kto (co) to jest tancerka?

Kto (co) to jest braciszek?

Kto (co) to jest wątróbka?

Technika 2 - umiejętność dekodowania konstrukcji w postaci cech semantycznych składających się na ich znaczenie strukturalne:

a. Derywaty transpozycyjne

Cierpienie. Czy to jest czynność, miejsce czy cecha? Dlaczego tak się nazywa? Czym różni się cierpieć i cierpienie? 
Doniesienie. Czy to jest czynność, miejsce czy cecha? Czym różni się donieść idoniesienie?

b. Derywaty mutacyjne

Handlarz. Czy to jest: pan, pani, rzecz czy miejsce? Dlaczego tak się nazywa? Czym różni się handel i handlarz?

Kolejarz. Czy to jest: pan, pani, rzecz czy miejsce? Dlaczego tak się nazywa? Czym różni się kolej i kolejarz?

Maturzysta. Czy to jest pan , pani, rzecz czy miejsce? Dlaczego tak się nazywa? Czym różni się matura i maturzysta?

Grzybica. Czy to jest: pan, pani, rzecz, miejsce? Dlaczego tak się nazywa? Czym różniq się grzyby i grzybica?

c. Derywaty modyfikacyjne

Maszynka. Co to jest? Dlaczego tak się nazywa? Czym różni się maszyna i maszynka? Czy maszynka jest mała?

Papierek. Co to jest? Dlaczego tak się nazywa? Czym różni się papier i papierek? Czy papierek jest mały?

Z a da ni e 2 - przebadano umiejętność tworzenia (kodowania) derywatów należących do poszczególnych kategorii słowotwórczych.

Technika 1 - umiejętność tworzenia konstrukcji na podstawie parafrazy słowotwórczej, na przykład:

a. Derywaty mutacyjne

Człowiek, który przeprowadza egzamin, to...

Człowiek, który dysponuje kapitałem, to...

Dziecko, które chodzi do przedszkola, to...

Sklep, w którym sprzedaje piekarz, to...

Miejsce, w którym rozłożono obóz, to...

Miejsce, gdzie leczy się ludzi, to...

Urzq̨dzenie, które pali, to...

Urzq̨dzenie, które odbiera fale, to...

Człowiek, który jest samotny, to...

Drzewo, na którym rosną figi, to... 
a. Derywaty modyfikacyjne

Aktor, który jest kobieta, to...

Mała gablota to...

Technika 2 - umiejętność tworzenia derywatów na podstawie cech semantycznych składających się na ich znaczenie strukturalne, na przykład:

a. Derywaty mutacyjne

Film + robić + człowiek (co to jest?)

Parafia + należeć + człowiek (kto to jest?)

Urządzenie + chłodzić (co to jest?)

Elektryczny + robić + miejsce (co to jest?)

Garbaty + człowiek (kto to jest?)

Kawa + drzewo (co to jest?)

b. Derywaty modyfikacyjne

Hrabia + żona (kto to jest?)

Zadanie 3 - przebadano definiowanie wyrazów wieloznacznych. Przy każdym wyrazie umieszczono pytania pomocnicze, by wydobyć sposoby interpretacji znaczenia, na przykład:

Fala. Co to jest? Jak wygląda? Gdzie można ja zobaczyć? Czy to jest tylko rzecz?

Jaja. Jak wyglądaja? Jakie sq rodzaje? Czy są tylko do jedzenia?

Babka. Jak wygląda? Z czego jest? Czy jest tylko do jedzenia?

Pasztet. Co to jest? Jak wygląda? Czy jest tylko do jedzenia? Kogo się tak nazywa?

Deska. Co to jest? Jak wygląda? Do czego służy? Jak można jeszcze wykorzystać deskę?

Lizak. Co to jest? Jak wygląda? Czy tylko go można jeść?

Balon. Co to jest? Jak wygląda? Do czego służy? Jakie są rodzaje balonu?

Kaczka. Co to jest? Jak wygląda? Czy kaczka jest tylko ptakiem? Co można jeszcze nazwać kaczką?

Lód. Co to jest? Jak wygląda? Jakie sq rodzaje? Gdzie występuje?

Dama. Co to jest? Jak wygląda? Gdzie występuje? Na kogo tak mówimy?

Galeria. Co to jest? Jak wygląda? Czy to jest tylko miejsce? 
Ikona. Co to jest? Do czego służy? Gdzie jest? Czy na kogoś tak mówimy?

Bałwan. Co to jest? Jak wyglada? Gdzie jest? Mówimy tak na kogoś?

Demon. Co to jest? Kim jest? Jaki jest?

Fajka. Co to jest? Jak wygląda? Do czego służy?

Jazda. Co to jest? Co wtedy się dzieje?

Baran. Co to jest? Jak wygląda? Czy to jest tylko zwierzę?

Bagno. Co to jest? Jak wygląda? Gdzie jest? Czy jest zwiq̨zane z jakimś wydarzeniem?

Bajka. Co to jest? Dla kogo jest? Czy bajkę tylko się opowiada dzieciom?

Pajac. Co to jest? Jak wygląda? Czy na kogoś tak mówimy?

Adwokat. Co to jest? Kto to jest? Gdzie jest? Czy tylko tak określamy człowieka, a może jeszcze jaką́s rzecz?

Papuga. Co to jest? Jak wygląda? Czy jest tylko ptakiem? Na kogoś tak mówimy?

W zadaniu 2 nie uwzględniłem derywatów transpozycyjnych, ponieważ bardzo trudno było zmotywować pacjentkę do utworzenia konstrukcji transpozycyjnych. Przyjmuję za Ewą Muzyką-Furtak, że dzieciom z uszkodzonym słuchem trudniej jest zrozumieć funkcję gramatyczną formantu w derywacji transpozycyjnej, toteż wydają się one im funkcjonalnie nieuzasadnione (Muzyka-Furtak 2015: 181). Przypuszczam, że w przypadku pacjentów z niepełnosprawnością intelektualną jest podobnie. Nie traktuję powyższej metody jako jedynej słusznej, dlatego że osoby z niepełnosprawnością intelektualną stanowią bardzo zróżnicowaną językowo grupę. Zastosowana metoda badawcza jest jedynie wstępem do badań pilotażowych, w trakcie dalszych badań będzie modyfikowana.

\section{Opis przypadku}

Sara jest osobą niepełnosprawną intelektualnie w stopniu lekkim. Urodziła się z podejrzeniem cytomegalii (infekcji wewnątrzmacicznej) $)^{5}$. W okresie okołoporodowym występowały u Sary problemy z termoregulacją, co powodowało sinienie. Od urodzenia u badanej istniała konieczność uzupełniania deficytów cukru.

Pojedyncze słowa Sara zaczęła wypowiadać po ukończeniu trzeciego roku życia, a zdania dopiero w wieku szkolnym. Obecnie Sara jest w stanie posługiwać się

\footnotetext{
${ }^{5}$ Cytomegalia wrodzona, łac. cytomegalia congenita, to zakażenie płodu wywołane wirusem cytomegalii CMV (Borębowicz 2016: 336-337). Ryzyko wystąpienia ciężkich wad neurorozwojowych u dziecka jest znacznie większe w wyniku pierwotnej infekcji u ciężarnej kobiety. U noworodków z infekcją CMV stwierdza się zapalenie siatkówki, naczyniówki, małoocze, żółtaczkę, głuchotę i zaburzenia rozwoju psychoruchowego (Kawalec, Grenda, Ziółkowska 2015: 988-989).
} 
krótkimi zdaniami, jest w stanie prowadzić i podtrzymywać konwersację. Badana nie czyta całego zdania. Czytając, pacjentka widzi tylko pojedyncze wyrazy, trudno jest jej skupić uwagę na całym zdaniu. Nie jest w stanie tworzyć zdań wielokrotnie złożonych, głównie posługuje się równoważnikami zdań. Podczas badania pedagogicznego stwierdzono również zaburzenia słuchu fonemowego.

W wyniku badań psychologicznych u Sary zauważono zaburzenia procesów myślenia i wnioskowania, jak również obniżone tempo uczenia się nowych informacji o charakterze słownym. Dodatkowy kłopot sprawia jej selekcja i ocena zachowań oraz wyprowadzanie poprawnych wniosków.

W badaniu neurologicznym SPECT ${ }^{6}$ zaobserwowano zmiany, które dominują na pograniczu płatów ciemieniowo-potylicznego prawego i lewego oraz okolic czołowych tylnych. Sara ma również zdiagnozowany niedosłuch - ok. 50 decybeli w uchu prawym i 70 decybeli w uchu lewym. Konsekwencją niedosłuchu jest przede wszystkim brak pewności w kontaktach personalnych, ponieważ pacjentka czasami nie usłyszy tego, co zostało do niej powiedziane. Jest nadwrażliwa na dotyk i na bodźce słuchowe. Wyżej wymienione czynniki miały ogromny wpływ na zaburzenia w rozwoju mowy. Pacjentka była wychowywana w sprzyjających warunkach, rodzice Sary bardzo troszczyli się o jej rozwój. U rodziców i rodzeństwa badanej nie odnotowano niepełnosprawności intelektualnej.

\section{Analiza materiału}

\section{Konstrukcje słowotwórcze}

1. Sposoby dekodowania derywatów transpozycyjnych (kategorie nazw czynności i nazw abstrakcyjnych cech)

a. Formułowanie parafrazy słowotwórczej (technika 1)

W opisie metajęzykowym, by właściwie dekodować formację słowotwórczą, należy poprawnie sformułować parafrazę słowotwórczą, ale nie jest to warunek konieczny. Osoby z niepełnosprawnością intelektualną w stopniu lekkim mają problemy z budowaniem zdań. Wykształcona dostatecznie kompetencja składniowa ułatwia formułowanie parafrazy słowotwórczej, będącej typem wypowiedzi definicyjnej. U badanej widoczne są kłopoty z właściwym konstruowaniem parafrazy, ale nie zawsze - badana powtarza w definicji konstrukcję transpozycyjną, podejmuje na swój sposób próbę odczytania derywatów, na przykład:

Co to jest głupstwo? - ktoś wtedy zrobi głupstwo.

Co to jest dokonanie? - wtedy, kiedy człowiek coś dokonuje.

Co to jest efektywność? - ktoś, kiedy jest efektywny.

${ }^{6}$ Ang. single-photon emission computed tomography. 
b. Umiejętność eksplikacji cech semantycznych (technika 2)

Odczytanie tylko znaczenia realnego, z pominięciem znaczenia strukturalnego, brak rozumienia relacji formalno-semantycznych, na przykład:

Cierpienie - wtedy, kiedy ktośchoruje, cierpienie to jest ból, cierpienie to jest czynność.

Doniesienie - donosić na kogoś, donieść na kogoś na policję.

2. Sposoby dekodowania derywatów mutacyjnych (kategorie nazw wykonawców czynności, nazw narzędzi, nazw nosicieli cech, nazw miejsc)

a. Formułowanie parafrazy słowotwórczej (technika 1)

Specyficzny sposób formułowania parafrazy słowotwórczej, pomimo wskazania wyrazu podstawowego i funkcji formantu, na przykład:

Kto to jest marzyciel? - o czymś człowiek marzy.

Co to jest palmiarnia? - tam, gdzie rosna palmy.

Odczytanie tylko znaczenia realnego:

Kto to jest rozbójnik? - człowiek, który rabuje.

Wskazanie relacji formalno-semantycznej, na przykład:

Kto (co) to jest sernik? - to ciasto z serem.

b. Umiejętność eksplikacji cech semantycznych (technika 2)

Identyfikacja wyrazu podstawowego i funkcji formantu, na przykład:

Grzybica - grzybica to choroba, grzyby rosna w lesie.

Kolejarz - kolejarz pracuje na kolei, kolej jeździ po torach.

Skupianie się tylko na odczytaniu znaczenia realnego, pominięcie wyrazu podstawowego, na przykład:

Handlarz - to osoba, która sprzedaje, różni się tym, że handel to sprzedaż.

Maturzysta - to osoba, która zdaje egzamin, matura to jest egzamin.

3. Sposoby kodowania derywatów mutacyjnych (kategorie nazw wykonawców czynności, nazw narzędzi, nazw nosicieli cech, nazw miejsc)

Poprawne utworzenie konstrukcji słowotwórczej, wykorzystanie właściwego formantu, na przykład:

Technika 1:

Człowiek, który przeprowadza egzamin, to - egzaminator.

Drzewo, na którym rosną figi, to - figowiec. 
Sklep, w którym sprzedaje piekarz, to - piekarnia.

Dziecko, które chodzi do przedszkola, to - przedszkolak.

Miejsce, w którym rozłożono obóz, to - obozowisko.

Człowiek, który jest samotny, to - samotnik.

Technika 2:

Urządzenie + chłodzić (co to jest?) - chłodziarka.

Elektryczny + robić + miejsce (co to jest?) - elektrownia.

Film + robić + człowiek (co to jest?) - filmowiec.

Garbaty + człowiek (kto to jest?) - garbus.

Kawa + drzewo (co to jest?) - kawowiec.

Parafia + należeć + człowiek (kto to jest?) - parafianin.

Niepoprawne utworzenie formacji wynikające z braku znajomości znaczenia strukturalnego (technika 1), na przykład:

Urządzenie, które pali, to - piecyk.

Urządzenie, które odbiera fale, to - radio.

Miejsce, gdzie leczy się ludzi, to - szpital.

Człowiek, który dysponuje kapitałem, to - brak odpowiedzi.

4. Sposoby dekodowania derywatów modyfikacyjnych (kategorii nazw żeńskich i nazw deminutywnych)

a. Formułowanie parafrazy słowotwórczej (technika 1)

Cząstkowe, wątpliwe odczytywanie znaczenia strukturalnego, na przykład:

Kto to jest braciszek? - to jest małe dziecko, to braciszek.

Niewłaściwa interpretacja formacji słowotwórczej, na przykład:

Kto to jest tancerka? - to człowiek, który tańczyć.

Kto to jest kocica? - to jest dzika kotka.

Kto to jest wątróbka? - to jest u człowieka wątroba.

Kłopoty interpretacyjne powyższych derywatów, jakie miała Sara, wynikają z braku rozumienia funkcji gramatycznej formantu. Sufiks -ica interpretuje $w$ funkcji ekspresywnej w przypadku wyrazu kocica. Zauważyłem zawężenie treści definicji derywatu wątróbka w znaczeniu 'narząd, organ', a nie 'potrawa', 'mała wątroba'. 
b. Umiejętność eksplikacji cech semantycznych (technika 2)

Niepoprawna identyfikacja wyrazu podstawowego i znaczenia formantu, brak wskazania relacji formalno-semantycznej, na przykład:

Maszynka - tak, jest duża maszyna do szycia, maszyna do pisania.

Papierek - kartka papieru jest duża i mała.

5. Sposoby kodowania derywatów modyfikacyjnych (kategorii nazw żeńskich i nazw deminutywnych)

Wykorzystanie zgodnych z normą formantów do utworzenia konstrukcji modyfikacyjnych (technika 1), na przykład:

Aktor, który jest kobietą, to - aktorka.

Mała gablota to - gablotka.

Użycie innego formantu do utworzenia konstrukcji feminatywnej (technika 2), na przykład:

Hrabia + żona (kto to jest?) - hrabianka.

II. Wyrazy wieloznaczne

Poszczególne wyrazy Sara definiowała, bazując głównie na swojej wiedzy i tym, co jest jej bliższe, znane. Podaje cechy konieczne, kategorialne, prototypowe. Dla pacjentki podstawą tworzenia kategorii jest obraz percepcyjny, który powstał w wyniku zgromadzenia obrazów wielu egzemplarzy. Trudno nie zgodzić się z twierdzeniem Eleonor Rosch, że wyodrębnienie kategorii dokonuje się na podstawie prototypu, prototyp kształtuje się w naturalny sposób na podstawie danych spostrzeżeniowych w kategoriach percepcyjnych (za: Borowiec 2014: 53)7.

W definicji wyrazu bałwan Sara podała znaczenie 'bałwanica'. Prawdopodobnie ogromny wpływ wywarł tutaj mechanizm słowotwórczy; badana analogicznie do wyrazów tygrys : tygrysica, kot : kocica utworzyła nazwę żeńską.

W tabeli 2 zaprezentowano odpowiedzi Sary.

${ }^{7}$ Szerzej koncepcję E. Rosch omawia w swojej pracy Helena Borowiec (zob. 2014: 49-53). 
Tab. 2. Odpowiedzi pacjentki

\begin{tabular}{|c|c|c|c|c|c|c|c|c|c|}
\hline $\begin{array}{l}\text { Wy- } \\
\text { raz }\end{array}$ & $\begin{array}{c}\text { Rodzaj } \\
\text { (49) }\end{array}$ & \begin{tabular}{|c} 
Kategoria \\
nadrzęd- \\
na \\
$(10)$
\end{tabular} & $\begin{array}{l}\text { Pocho- } \\
\text { dzenie } \\
\text { (10) }\end{array}$ & $\begin{array}{c}\text { Właści- } \\
\text { wości } \\
(21)\end{array}$ & $\begin{array}{c}\text { Prze- } \\
\text { znaczenie } \\
\text { (7) }\end{array}$ & $\begin{array}{c}\text { Kształt } \\
(2)\end{array}$ & $\begin{array}{l}\text { Czyn- } \\
\text { ność } \\
(13)\end{array}$ & $\begin{array}{l}\text { Miejsce } \\
\text { występo- } \\
\text { wania } \\
\text { (14) }\end{array}$ & $\begin{array}{c}\text { Okolicz- } \\
\text { ności } \\
\text { (3) }\end{array}$ \\
\hline fala & $\begin{array}{l}\text { morska, radiowa, } \\
\text { powodziowa, } \\
\text { tsunami, upału, } \\
\text { uderzenia, ra- } \\
\text { żenia }\end{array}$ & - & - & $\begin{array}{l}\text { magne- } \\
\text { tyczna, }\end{array}$ & - & - & - & - & - \\
\hline jaja & $\begin{array}{l}\text { kurze, strusie, } \\
\text { kacze, wielkanoc- } \\
\text { ne, w czekoladzie }\end{array}$ & - & - & świeże & - & duże & - & - & $\begin{array}{l}\text { Mówi się, } \\
\text { ale jaja }\end{array}$ \\
\hline $\begin{array}{l}\text { bab- } \\
\text { ka }\end{array}$ & $\begin{array}{l}\text { ziemniaczana, } \\
\text { wielkanocna }\end{array}$ & $\begin{array}{l}\text { ciasto ze } \\
\text { śliwkami }\end{array}$ & - & z owocami & - & - & - & - & - \\
\hline $\begin{array}{l}\text { pasz- } \\
\text { tet }\end{array}$ & - & - & $\begin{array}{l}\text { z królika, } \\
\text { z kurcząt, } \\
\text { barani }\end{array}$ & - & - & - & - & - & - \\
\hline deska & - & drzewo & z drewna & - & $\begin{array}{l}\text { do praso- } \\
\text { wania, do } \\
\text { krojenia, do } \\
\text { układania } \\
\text { ubrań, do } \\
\text { przewijania } \\
\text { dziecka }\end{array}$ & - & - & - & - \\
\hline lizak & na patyku & - & - & jest słodki & do lizania & - & - & - & - \\
\hline balon & $\begin{array}{l}\text { dmuchany, } \\
\text { gumowy, na } \\
\text { sznurku }\end{array}$ & - & - & - & - & $d u z ̇ y$ & lata & - & - \\
\hline $\begin{array}{l}\text { kacz- } \\
\text { ka }\end{array}$ & - & ptak & - & $\begin{array}{l}\text { nadzie- } \\
\text { wana, } \\
\text { pieczona, } \\
\text { potrawa }\end{array}$ & - & - & $\begin{array}{l}\text { lata, } \\
\text { pływa, } \\
\text { kwacze }\end{array}$ & w stawie & - \\
\hline lód & kostka, tafla, kra & - & - & $\begin{array}{l}\text { zimny, } \\
\text { śliski }\end{array}$ & - & - & - & $\begin{array}{l}\text { na Bałtyku, } \\
\text { na jeziorze, } \\
\text { chodniku }\end{array}$ & - \\
\hline dama & $\begin{array}{l}\text { Królowa Pik, } \\
\text { w kartach, w kier- } \\
\text { kach, }\end{array}$ & - & - & - & - & - & rządzi & $\begin{array}{l}\text { na dworze } \\
\text { królewskim }\end{array}$ & - \\
\hline $\begin{array}{l}\text { gale- } \\
\text { ria }\end{array}$ & Handlowa, sztuki & - & - & - & - & - & - & $\begin{array}{l}\text { Sklepy, } \\
\text { Przymorze, } \\
\text { Bałtycka, } \\
\text { Metropolia }\end{array}$ & - \\
\hline ikona & $\begin{array}{l}\text { muzyki, idol, } \\
\text { bożek, gwiazda }\end{array}$ & - & - & - & - & - & - & \begin{tabular}{|l} 
na kompu- \\
terze
\end{tabular} & - \\
\hline $\begin{array}{l}\text { bał- } \\
\text { wan }\end{array}$ & - & - & - & $\begin{array}{l}\text { ze śniegu, } \\
\text { biały }\end{array}$ & - & - & - & w kościele & $\begin{array}{l}\text { mówi się, } \\
\text { ty bałwa- } \\
\text { nie }\end{array}$ \\
\hline $\begin{array}{l}\text { de- } \\
\text { mon }\end{array}$ & - & aniot & $\begin{array}{l}\text { dziecko } \\
\text { szatana }\end{array}$ & $\begin{array}{l}\text { zły, świa- } \\
\text { tłości, } \\
\text { czarny }\end{array}$ & - & - & - & - & - \\
\hline
\end{tabular}




\begin{tabular}{|c|c|c|c|c|c|c|c|c|c|}
\hline $\begin{array}{l}\text { Wy- } \\
\text { raz }\end{array}$ & $\begin{array}{l}\text { Rodzaj } \\
\text { (49) }\end{array}$ & $\begin{array}{c}\text { Kategoria } \\
\text { nadrzęd- } \\
\text { na } \\
\text { (10) }\end{array}$ & $\begin{array}{l}\text { Pocho- } \\
\text { dzenie } \\
\text { (10) }\end{array}$ & $\begin{array}{l}\text { Właści- } \\
\text { wości } \\
(21)\end{array}$ & $\begin{array}{c}\text { Prze- } \\
\text { znaczenie } \\
\text { (7) }\end{array}$ & $\begin{array}{c}\text { Kształt } \\
(2)\end{array}$ & $\begin{array}{l}\text { Czyn- } \\
\text { ność } \\
(13)\end{array}$ & $\begin{array}{l}\text { Miejsce } \\
\text { występo- } \\
\text { wania } \\
\text { (14) }\end{array}$ & $\begin{array}{c}\text { Okolicz- } \\
\text { ności } \\
\text { (3) }\end{array}$ \\
\hline fajka & $\begin{array}{l}\text { papieros, indiań- } \\
\text { ska, pokoju }\end{array}$ & $\begin{array}{l}\text { szkodzi } \\
\text { zdrowiu }\end{array}$ & \begin{tabular}{|l} 
kapitana \\
statku, \\
dziadka, \\
hrabiego \\
\end{tabular} & - & - & - & dymi & - & - \\
\hline jazda & $\begin{array}{l}\text { samochodem, na } \\
\text { rowerze, konno, } \\
\text { na rolkach, bez } \\
\text { trzymanki, po- } \\
\text { ciagiem, autobu- } \\
\text { sem, tramwajem, } \\
\text { na tyżwach }\end{array}$ & - & - & - & - & - & - & - & - \\
\hline baran & - & zwierzę & - & $\begin{array}{l}\text { ma rogi, } \\
\text { kopyta }\end{array}$ & wetna & - & beczy & $\begin{array}{l}\text { na pastwi- } \\
\text { skach }\end{array}$ & $\begin{array}{l}\text { mówi się } \\
\text { ty bara- } \\
\text { nie }\end{array}$ \\
\hline $\begin{array}{l}\text { ba- } \\
\text { gno }\end{array}$ & - & zbiornik & - & $\begin{array}{l}\text { jest czarne, } \\
\text { jest głębo- } \\
\text { kie }\end{array}$ & - & - & wciaga & $\begin{array}{l}\text { W lesie, } \\
\text { siedlisko } \\
\text { komarów }\end{array}$ & - \\
\hline bajka & $\begin{array}{l}\text { na dobranoc, } w \\
\text { TV, kreskówka, } \\
\text { animowana, } \\
\text { obrazkowa, } \\
\text { rysowana }\end{array}$ & $\begin{array}{l}\text { opowia- } \\
\text { danie }\end{array}$ & - & $\begin{array}{l}\text { wesoła, } \\
\text { smutna }\end{array}$ & - & - & $\begin{array}{l}\text { czyta- } \\
\text { nie dla } \\
\text { dzieci }\end{array}$ & - & - \\
\hline pajac & - & kukiełka & $\begin{array}{l}\text { zrobiony } \\
\text { z różnych } \\
\text { materia- } \\
\text { łów }\end{array}$ & ma czapkę & - & - & $\begin{array}{l}\text { robipa- } \\
\text { jacyki, } \\
\text { paja- } \\
\text { cuje, } \\
\text { skacze }\end{array}$ & - & - \\
\hline $\begin{array}{l}\text { ad- } \\
\text { wo- } \\
\text { kat }\end{array}$ & pełnomocnik & - & - & - & - & - & $\begin{array}{l}\text { pro- } \\
\text { wadzi } \\
\text { w sq- } \\
\text { dzieroz- } \\
\text { prawy }\end{array}$ & $\begin{array}{l}\text { pracuje } \\
\text { w kancelarii } \\
\text { adwokac- } \\
\text { kiej }\end{array}$ & - \\
\hline $\begin{array}{l}\text { pa- } \\
\text { puga }\end{array}$ & - & $\begin{array}{l}\text { jest pta- } \\
\text { kiem }\end{array}$ & - & $\begin{array}{l}\text { jest kolo- } \\
\text { rowa }\end{array}$ & - & - & - & $\begin{array}{l}\text { mieszka } \\
\text { w zoo }\end{array}$ & - \\
\hline
\end{tabular}

Źródło: opracowanie własne.

\section{Podsumowanie}

Zaprezentowana wyżej analiza jest jedynie próbą opisu kompetencji leksykalnej i semantycznej osoby niepełnosprawnej intelektualnie w stopniu lekkim. Według Aliny Maciejewskiej trudno jest ocenić precyzyjnie znaczenie jednostek w przypadku osób z zaburzeniami komunikacji językowej (zob. Maciejewska 2012: 173). Przytaczane przez badaną definicje znacząco odbiegają od normy, ponieważ składają się tylko z cech koniecznych i wystarczających do identyfikacji wyrazów. Pacjentka nie buduje zdań spełniających wymogi parafrazy słowotwórczej, by przywołać treść danego słowa. W charakterystyczny sposób opisuje przedmioty, skupia się głównie na ich wyglądzie, budowie, zastosowaniu. Wiedza pacjentki głównie opiera się na myśleniu 
konkretno-obrazowym, odbieranym zmysłowo. Należy zauważyć, że podejmuje ona jednak próbę definiowania na swój sposób, opierając się na przymiotnikach. Istotne jest to, że Sara przy definiowaniu wyrazów wieloznacznych podaje tylko jedno znaczenie, nie dostrzega wieloznaczności i nie wyróżnia znaczenia abstrakcyjnego, nie dokonuje też przesunięć znaczeniowych, co jest wynikiem zarówno jej ograniczonego zasobu wiedzy o świecie, jak i posiadania przeciętnej kompetencji językowej. Niewykształcona w pełni kompetencja językowa utrudnia Sarze budowanie parafrazy słowotwórczej i odczytywanie znaczenia strukturalnego, szczególnie w odniesieniu do derywatów modyfikacyjnych.

Wyciąganie jednoznacznych wniosków w przypadku sprawności językowej osób upośledzonych umysłowo jest bardzo skomplikowane. Przytoczone powyżej przykłady wykazują, że w celu prowadzenia pracy terapeutycznej należałoby stworzyć specjalny leksykon - przyjazny w procesie edukacji osób upośledzonych umysłowo, uwzględniający nieskomplikowany sposób przyswajania przez nich wiedzy o świecie. W Finlandii opracowano już taką uproszczoną wersję języka fińskiego dla osób niepełnosprawnych intelektualnie (selkokieli) (zob. Wojan 2016). Być może warto podjąć takie działania również na gruncie języka polskiego.

\section{Literatura}

Banaszkiewicz A., 2015, Studium przypadku (case study) jako metoda badań logopedycznych [w:] Metodologia badań logopedycznych z perspektywy teorii i praktyki, red. S. Milewski, K. Kaczorowska-Bray, Gdańsk: Harmonia Universalis.

Bartmiński J., 2007, Językowe podstawy obrazu świata, wyd. 2 uzup., Lublin: Wydawnictwo Uniwersytetu Marii Curie-Skłodowskiej.

Binkuńska E., 2012, Procesy definiowania u dzieci cztero-, szcześcio- i ośmioletnich [w:] Logopedia: wybrane aspekty historii, teorii i praktyki, red. S. Milewski, K. Kaczorowska-Bray, Gdańsk: Harmonia Universalis.

Borowiec H., 2014, Dziecięce rozumienie świata. Studium lingwistyczne, Lublin: Wydawnictwo Uniwersytetu Marii Curie-Skłodowskiej.

Błeszyński J., 2012, Diagnoza rozwoju mowy osób z niepełnosprawnościq intelektualna [w:] Diagnoza logopedyczna, red. E. Czaplewska, S. Milewski, Sopot: Gdańskie Wydawnictwo Psychologiczne.

Borębowicz G., 2016, Położnictwo i ginekologia, t. 1-2, Warszawa: Wydawnictwo Lekarskie PZWL.

Grabias S., 2012, O ostrość refleksji naukowej: przedmiot logopedii i procedury logopedycznego postępowania [w:] Logopedia: wybrane aspekty historii, teorii i praktyki, Gdańsk: Harmonia Universalis.

Grabias S. et al., red., 2015, Postępowanie logopedyczne. Standardy terapii [w:] Logopedia: standardy postępowania logopedycznego, Lublin: Wydawnictwo Uniwersytetu Marii Curie-Skłodowskiej.

Grzegorczykowa R., 1972, Zarys słowotwórstwa polskiego: słowotwórstwo opisowe, Warszawa: Wydawnictwa Uniwersytetu Warszawskiego.

Grzegorczykowa R., 2010, Wprowadzenie do semantyki językoznawczej, wyd. 4 rozsz., Warszawa: Wydawnictwo Naukowe PWN.

Grzegorczykowa R., Szymanek B., 2001, Kategorie słowotwórcze w perspektywie kognitywnej [w:] Encyklopedia kultury polskiej XX wieku, t. 2: Współczesny język polski, red. J. Bartmiński, Lublin: Wiedza o kulturze. 
Kaczorowska-Bray K., 2012, Zaburzenia komunikacji językowej w grupie osób z niepełnosprawnościq intelektualnq [w:] Diagnoza i terapia logopedyczna osób z niepełnosprawnościq intelektualnq, red. J.J. Błeszyński, K. Kaczorowska-Bray, Gdańsk: Harmonia Universalis.

Kaczorowska-Bray K., 2017, Zaburzenia mowy u dzieci z niepełnosprawnościq intelektualnq - trudności badawcze [w:] Studia logopedyczno-lingwistyczne: księga jubileuszowa z okazji 70-lecia urodzin Profesora Edwarda Łuczyńskiego, red. S. Milewski, K. Kaczorowska-Bray, B. Kamińska, Gdańsk: Harmonia Universalis.

Kawalec W., Grenda R., Ziółkowska H., red., 2015, Pediatria, t. 2, Warszawa: Wydawnictwo Lekarskie PZWL.

Kowalik S., 2005, Psychologia niepełnosprawności umysłowej [w:] Psychologia kliniczna, red. H. Sęk, t. 2, Warszawa: Wydawnictwo Naukowe PWN.

Maciejewska A., 2012, Sprawność definiowania w rozwoju mowy i niektórych jej zaburzeniach [w:] Logopedia: wybrane aspekty historii, teorii i praktyki, red. S. Milewski, K. Kaczorowska-Bray, Gdańsk: Harmonia Universalis.

Marszałek M., 2010, Rozumienie znaczeń słów przez dzieci z zespołem Downa, "Nowa Logopedia”, t. 1, Kraków: Collegium Columbinum.

Michalik M., 2010, Między językiem, myśleniem a rzeczywistościq - budowanie kompetencji gramatyczno-leksykalnej dziecka podejrzewanego o upośledzenie intelektualne: studium przypadku, „Nowa Logopedia", t. 1, Kraków: Collegium Columbinum.

Michalik M., 2013, Porażona interakcja. Koncpecja interakcji językowej jako głos w sprawie dyzartrii o podłożu mózgowego porażenia dziecięcego, "Nowa Logopedia”, t. 4, Kraków: Collegium Columbinum.

Muzyka-Furtak E., 2010, Konstrukcje słowotwórcze w świadomości językowej dzieci niesłyszących, Lublin: Wydawnictwo Uniwersytetu Marii Curie-Skłodowskiej.

Muzyka-Furtak E., 2015, Wyrazy pochodne w słowniku dzieci z uszkodzeniami słuchu [w:] red. E. Muzyka-Furtak, Surdologopedia: teoria i praktyka, Gdańsk: Harmonia Universalis.

Nowakowska-Kempa I., 1993, Definiowanie znaczenia wyrażeń w kognitywizmie. Wybrane zagadnienia [w:] O definicjach i definiowaniu, red. J. Bartmiński, R. Tokarski, Lublin: Wydawnictwo Uniwersytetu Marii Curie-Skłodowskiej.

Panasiuk J., 2013, Sprawności interakcyjne i komunikacyjne jako kryteria różnicowania zaburzeń rozwojowych, "Nowa Logopedia” , t. 4, Kraków: Collegium Columbinum.

Panasiuk J., 2015, Rozumieć po ludzku: od kodu polikonkretnego do hierarchicznego $w$ rozumieniu świata, "Nowa Logopedia", t. 6, Kraków: Collegium Columbinum.

Sobol E., Drabik L., red., 2007, Szkolny słownik języka polskiego PWN, Warszawa: Wydawnictwo Naukowe PWN.

Tarkowski Z., Góral-Półrola J., 2012, Komunikacja słowna z udziałem osoby upośledzonej umysłowo [w:] Wprowadzenie do neurologopedii, red. A. Obrębowski, Poznań: Termedia Wydawnictwa Medyczne.

Tarkowski Z., 2005, Mowa osób upośledzonych umysłowo i jej zaburzenia [w:] Podstawy neurologopedii, red. T. Gałkowski, E. Szeląg, G. Jastrzębowska, Opole: Wydawnictwo Uniwersytetu Opolskiego. Wielki słownik języka polskiego, 2017, Instytut Języka Polskiego PAN, http://www.wsjp.pl [dostęp: 30.03.2017].

Wojan K., 2016, Język fiński w teorii i praktyce, Gdańsk: Wydawnictwo Uniwersytetu Gdańskiego. 